\title{
Productivity and Nitrogen Use Efficiency of Wheat Varieties in Relation to Nitrogen Levels under Rainfed Conditions of North-western India
}

\author{
Hari Ram*, G.S. Mavi, Neha Gupta, S.S. Dhaliwal and V.S. Sohu
}

Department of Plant Breeding \& Genetics, Punjab Agricultural University, Ludhiana 141004, Punjab, India

*Corresponding author

\section{A B S T R A C T}

\begin{tabular}{|l|}
\hline K e y w o r d s \\
Nitrogen use \\
efficiency, \\
Productivity, \\
Rainfed conditions, \\
Varieties, Wheat. \\
\hline Article Info \\
\hline $\begin{array}{l}\text { Accepted: } \\
\text { 07 September } 2017 \\
\text { Available Online: } \\
10 \text { October } 2017\end{array}$ \\
\hline
\end{tabular}

\begin{abstract}
Although area of wheat (Triticum aestivum L.) under rainfed conditions is less in Northwestern India but selection of appropriate variety plays an important role in the success of crop. The experiment was conducted at the Punjab Agricultural University, Ludhiana $\left(30^{\circ}\right.$ 54' $\mathrm{N}$ and $75^{\circ} 48^{\prime} \mathrm{E}$; $247 \mathrm{~m} \mathrm{ASL}$ ) during winter seasons of 2009-10 and 2010-11 on loamy sand soil with low in organic matter. The experiment was laid out in a split plot design with three nitrogen levels [N 40,60 and $80 \mathrm{~kg} \mathrm{~N} / \mathrm{ha}$ ] as main plot treatment and four wheat varieties (C 306, PBW 175, PBW 396 and WH 1080) as subplot treatments with three replications. The grain yield recorded in 60 and $80 \mathrm{~kg} \mathrm{~N} /$ ha was 28.5 and $38.5 \%$ higher than that recorded in $40 \mathrm{~kg} \mathrm{~N} / \mathrm{ha}$, respectively. But lower dose of nitrogen (40 kg N/ha) had significantly higher nitrogen use efficiency than other doses of $\mathrm{N}$ application. Rainfed wheat variety, PBW 175 recorded the highest grain yield and nitrogen use efficiency which was significantly higher than WH 1080, PBW 175 and PBW 396.
\end{abstract}

\section{Introduction}

Wheat (Triticum aestivum L.) is mainly used as a staple food providing more protein than any other cereal crop. It can be consumed in different forms. Wheat straw is mainly used as animal feed. However, nutrient requirement of this cereal crop varies greatly in response to variety and environmental conditions prevailed during initial crop growth. Among the critical nutrients for plant growth, nitrogen plays a significant role. It is constituent of nucleic acids, amino acids, enzymes, and photosynthetic pigments. Use of optimum amount of nitrogen is considered as a key to obtain bumper and quality crop of wheat. Plants take up most of their nitrogen as the ammonium $\left(\mathrm{NH}_{4}{ }^{+}\right)$or nitrate $\left(\mathrm{NO}_{3}{ }^{-}\right)$form.
Nitrogen is necessary for chlorophyll biosynthesis which is the main pigment involved in photosynthesis. It is also an essential component of all amino acids and protein which are considered responsible for quality of wheat (Krishankumari et al., 2000). $\mathrm{N}$ requirement of wheat may be related to residual $\mathrm{N}$ in soil, differential cultivar response, microbial population in rhizosphere etc. As the soil water availability is less under rainfed condition, so, there are fewer chances for leaching of nitrogen. Selection of proper variety under rainfed conditions is an important task to get better yield. Generally, the varieties with taller plants and greater dry matter accumulation characters are considered 
suitable. As the varieties respond differentially to nitrogen dose (Benin et al., 2012; Kaur and Ram 2017), an experiment was planned to study the effect of nitrogen on yield attributes and yield of wheat under rainfed conditions in North-western (NW) India.

\section{Materials and Methods}

The field experiment was conducted at the Punjab Agricultural University, Ludhiana $\left(30^{\circ}\right.$ 54' $\mathrm{N}$ and $75^{\circ} 48^{\prime} \mathrm{E}$; $247 \mathrm{~m}$ ASL) during winter seasons of 2009-10 and 2010-11. Punjab, falls in NW India, has a sub-tropical climate with hot, wet summers and cool, dry winters. The soil of experimental site was loamy sand, low in organic matter $(2.9 \mathrm{~g} \mathrm{C} / \mathrm{kg})$ and slightly alkaline ( $\mathrm{pH}$ 7.9). The experiment was laid out in a split plot design with three replications, three nitrogen levels [N @ 40,60 and $80 \mathrm{~kg} \mathrm{~N} / \mathrm{ha}$ ] as main plot treatment and three wheat varieties (C 306, PBW 175, PBW 396 and WH 1080) as subplot treatments. Wheat crop was sown at the row spacing of $22.5 \mathrm{~cm}$ using seed rate of $100 \mathrm{~kg} / \mathrm{ha}$. The crop was raised without irrigation under rainfed conditions. Nitrogen was applied in the form of urea at the time of sowing. Phosphorus@30 kg $\mathrm{P}_{2} \mathrm{O}_{5} /$ ha was applied at the time of sowing in the form of DAP. Emergence count, tiller density (both total and effective tillers) were recorded from one metre row length and data were converted to per square metre. The grains/ear were calculated from randomly selected and manually threshed five ears in each sub plot. The sample of 1000-grains was collected from each plot, and weighed to present as gram. The crop biomass and grain yield were recorded at the time of harvesting and represented as quintal/ha. Nitrogen use efficiency was calculated by dividing grain yield with nitrogen applied. All the data were analyzed using standard method of ANOVA for split plot design.

\section{Results and Discussion}

Emergence, yield attributes, biological yield and phenology of rainfed wheat

\section{Performance in different years}

The highest emergence count, total tillers, effective tillers and biological yield recorded in 2010-11 was significantly higher than 2009-10 (Table 1). Although grains per earhead recorded were non-significant but test weight was significantly higher in 2009-10. Higher test weight in 2009-10 might be due to lower effective tillers which resulted in more assimilate translocation towards developing grain. The highest biological yield was recorded in 2010-11, which might be due to more number of total and effective tillers.

\section{Effect of nitrogen levels}

The emergence count was not significantly influenced with nitrogen levels. The highest total tillers, effective tillers, grains per earhead, test weight and biological yield was recorded in $80 \mathrm{~kg} \mathrm{~N} / \mathrm{ha}$. Grains per earhead recorded in $80 \mathrm{~kg} \mathrm{~N} / \mathrm{ha}$ was statistically similar to $60 \mathrm{~kg} \mathrm{~N} / \mathrm{ha}$. However, grains per earhead recorded in $60 \mathrm{~kg} \mathrm{~N} / \mathrm{ha}$ was statistically at par with $40 \mathrm{~kg} \mathrm{~N} / \mathrm{ha}$. Although, total tillers recorded in different nitrogen treatments were statistically at par with each other but total and effective tillers recorded in $80 \mathrm{~kg} \mathrm{~N} /$ ha were 6.9 and $7.6 \%$ higher than 40 $\mathrm{kg} \mathrm{N} / \mathrm{ha}$ and 2.6 and $1.1 \%$ higher than $60 \mathrm{~kg}$ $\mathrm{N} /$ ha, respectively. The test weight recorded in $80 \mathrm{~kg} \mathrm{~N} / \mathrm{ha}$ was the highest which was statistically at par with $60 \mathrm{~kg} \mathrm{~N} / \mathrm{ha}$ but significantly higher than that recorded on 40 $\mathrm{kg} \mathrm{N} / \mathrm{ha}$. The test weight recorded in $60 \mathrm{~kg}$ $\mathrm{N} /$ ha was also significantly higher than $40 \mathrm{~kg}$ $\mathrm{N} / \mathrm{ha}$. Higher yield attributes in higher nitrogen treatment was due to increased availability of nitrogen for the growth and development of the crop plants. The 
biological yield recorded in $80 \mathrm{~kg} \mathrm{~N} / \mathrm{ha}$ was significantly higher than 60 and $40 \mathrm{~kg} \mathrm{~N} / \mathrm{ha}$. A significant increase of 14.9 and $23.5 \%$ in biological yield was recorded in 60 and $80 \mathrm{~kg}$ $\mathrm{N} / \mathrm{ha}$ over $40 \mathrm{~kg} \mathrm{~N} / \mathrm{ha}$ application. Higher biological yield at higher nitrogen levels was due to increased rates of carbon assimilation resulting in higher yield attributing characters in this treatment. The phenology of wheat crop was not influenced by nitrogen levels.

\section{Effect of varieties}

The emergence count recorded in different varieties was statistically similar (Table 1). Tiller density and effective tillers recorded in variety PBW 175 were significantly higher than WH 1080, PBW 396 and C 306. However, the total and the effective tillers recorded in WH 1080, PBW 396 and C 306 were statistically similar. The grains per earhead recorded in WH 1080 were at par to PBW 396 and C 306 but significantly higher than PBW 175. It might be due the genotypic potential of the variety. Similar finding with different grains per erahead were also recorded by other scientists (Kaur and Ram, 2017). All the varieties differ among each other for 1000-grain weight but WH 1080 and PBW 396 were statistically similar. The wheat variety PBW 175 recorded the highest 1000-grain weight which was significantly higher than WH 1080, PBW 396 and C 306.

If the grains per earhead are less then generally such varieties have higher 1000grain weight (Benin et al., 2012). The highest biological yield was recorded in PBW 175 which was statistically similar to C 306 and WH 1080 but significantly higher than PBW 396. The variety PBW 175, C 306 and WH 1080 recorded 15.0, 14.8 and $9.2 \%$ higher biological yield than that recorded in PBW 396. It might be due higher yield attributing characters. The hearing was 4-6 days was late in PBW 396 but maturity was almost similar as compared to other varieties. So this character is also responsible for higher biological yield in these varieties.

\section{Grain yield}

The grain yield recorded in nitrogen level of $80 \mathrm{~kg} / \mathrm{ha}$ was the highest, which was significantly higher than $40 \mathrm{~kg} \mathrm{~N} / \mathrm{ha}$ but statistically at par with the $60 \mathrm{~kg} \mathrm{~N} / \mathrm{ha}$ (Table 2). The grain yield recorded in $60 \mathrm{~kg} \mathrm{~N} / \mathrm{ha}$ was also significantly higher than $40 \mathrm{~kg} \mathrm{~N} / \mathrm{ha}$. The magnitude of yield increase was recorded 28.5 and $38.5 \%$ higher in 60 and $80 \mathrm{~kg} \mathrm{~N} / \mathrm{ha}$ than $40 \mathrm{~kg} \mathrm{~N} / \mathrm{ha}$ respectively. The higher grain yield at higher dose of nitrogen might be due to high nitrogen availablility for chlorophyll and Rubisco biosynthesis, ultimately resulting in higher net assimilation rates for the growth and development which increased the yield attributes. Bawar et al., (2016) also reported wheat grain yield was similar at 50 and $75 \mathrm{~kg} \mathrm{~N} / \mathrm{ha}$.

Among the varieties, PBW 175 recorded the highest grain yield which was significantly higher than WH 1080, C306 and PBW 396. The grain yield recorded in C 306 and $\mathrm{WH}$ 1080 was statistically similar. The higher grain yield in PBW 175 was due to more number of total tillers, effective tillers and higher 1000-grain weight. Bawar et al., (2016) reported that grain yield of Shirvan was significantly higher than that in Bojnoord variety under rainfed conditions. Benin et al., (2012) also reported different grain yield in different varieties.

\section{Nitrogen use efficiency}

The highest nitrogen use efficiency was recorded in $40 \mathrm{~kg} \mathrm{~N} / \mathrm{ha}$ which was significantly higher than 60 ad $80 \mathrm{~kg} \mathrm{~N} / \mathrm{ha}$ (Table 3). Again $60 \mathrm{~kg} \mathrm{~N} / \mathrm{ha}$ recorded significantly higher nitrogen use efficiency than $80 \mathrm{~kg} \mathrm{~N} / \mathrm{ha}$. 
Int.J.Curr.Microbiol.App.Sci (2017) 6(10): 558-563

Table.1 Effect of different years, levels of nitrogen and varieties on yield attributes of wheat under rainfed conditions (Pooled mean of two years)

\begin{tabular}{|c|c|c|c|c|c|c|c|c|}
\hline Treatment & $\begin{array}{l}\text { Emergence } \\
\text { count }\left(\mathrm{m}^{-2}\right)\end{array}$ & $\begin{array}{c}\text { Total tillers } \\
\qquad\left(\mathrm{m}^{-2}\right)\end{array}$ & $\begin{array}{l}\text { Effective tillers } \\
\qquad\left(\mathrm{m}^{-2}\right)\end{array}$ & $\begin{array}{c}\text { Grain per } \\
\text { earhead }\end{array}$ & $\begin{array}{c}\text { Test weight } \\
\text { (g) }\end{array}$ & $\begin{array}{c}\text { Biological } \\
\text { yield }\left(\mathrm{q} \mathrm{ha}^{-1}\right)\end{array}$ & $\begin{array}{l}\text { Days to } \\
\text { earing }\end{array}$ & $\begin{array}{l}\text { Days to } \\
\text { maturity }\end{array}$ \\
\hline \multicolumn{9}{|l|}{ Year's effect } \\
\hline 2009-10 & 184.9 & 257.7 & 230.0 & 38.5 & 30.8 & 48.11 & 111 & 160 \\
\hline $2010-11$ & 226.8 & 343.2 & 320.9 & 38.5 & 29.1 & 52.44 & 111 & 159 \\
\hline $\operatorname{LSD}(\mathrm{P}=0.05)$ & 10.6 & 43.8 & 44.9 & NS & 1.5 & 4.00 & NS & NS \\
\hline \multicolumn{9}{|l|}{ Nitrogen levels } \\
\hline $40 \mathrm{~kg} \mathrm{~N} / \mathrm{ha}$ & 209.0 & 290 & 263 & 36.6 & 28.80 & 44.57 & 111 & 160 \\
\hline $60 \mathrm{~kg} \mathrm{~N} / \mathrm{ha}$ & 210.3 & 302 & 280 & 38.9 & 30.22 & 51.23 & 111 & 160 \\
\hline $80 \mathrm{~kg} \mathrm{~N} / \mathrm{ha}$ & 198.2 & 310 & 283 & 40.0 & 30.88 & 55.03 & 111 & 160 \\
\hline $\mathrm{CD}(0.05)$ & NS & NS & NS & 2.4 & 1.40 & 3.92 & NS & NS \\
\hline \multicolumn{9}{|l|}{ Varieties } \\
\hline C 306 & 200.3 & 295 & 271 & 38.3 & 27.81 & 52.57 & 110 & 160 \\
\hline PBW 175 & 203.1 & 320 & 292 & 36.3 & 32.63 & 52.69 & 111 & 160 \\
\hline PBW 396 & 215.4 & 292 & 269 & 38.7 & 29.37 & 45.81 & 115 & 159 \\
\hline WH 1080 & 204.5 & 294 & 270 & 40.6 & 30.06 & 50.04 & 109 & 160 \\
\hline $\operatorname{LSD}(\mathrm{P}=0.05)$ & NS & 12.9 & 12.4 & 2.4 & 1.36 & 2.74 & 0.48 & 0.28 \\
\hline
\end{tabular}


Table. 2 Grain yield ( $\mathrm{q} \mathrm{ha}^{-1}$ ) under rainfed conditions as influenced by levels of nitrogen and wheat varieties (pooled mean of two years)

\begin{tabular}{lcccc}
\hline \multirow{2}{*}{ Variety } & \multicolumn{4}{c}{ Nitrogen levels $(\mathrm{kg} / \mathrm{ha})$} \\
\cline { 2 - 5 } & 40 & 60 & 80 & Mean \\
\hline C 306 & 16.05 & 21.84 & 23.00 & 20.30 \\
PBW 175 & 18.97 & 23.15 & 23.54 & 21.89 \\
PBW 396 & 14.85 & 19.93 & 21.33 & 18.70 \\
WH 1080 & 16.55 & 20.48 & 24.15 & 20.40 \\
Mean & 16.61 & 21.35 & 23.01 & \\
\hline
\end{tabular}

LSD (P=0.05) Nitrogen levels: 1.66

Varieties: 1.21

Interaction: NS

Table.3 Nitrogen use efficiency ( $\mathrm{kg}$ grain $\mathrm{kg} \mathrm{N}_{\text {applied }}{ }^{-1}$ ) as influenced by different levels of nitrogen and wheat varieties under rainfed conditions (pooled mean of two years)

\begin{tabular}{lcccc}
\hline \multirow{2}{*}{ Variety } & \multicolumn{4}{c}{ Nitrogen levels $(\mathrm{kg} / \mathrm{ha})$} \\
\cline { 2 - 5 } & 40 & 60 & 80 & Mean \\
\hline C 306 & 40.13 & 36.40 & 28.75 & 35.09 \\
PBW 175 & 47.43 & 38.58 & 29.43 & 38.48 \\
PBW 396 & 37.13 & 33.22 & 26.66 & 32.33 \\
WH 1080 & 41.38 & 34.13 & 30.19 & 35.23 \\
Mean & 41.51 & 35.58 & 28.76 & \\
\hline
\end{tabular}

LSD ( $\mathrm{P}=0.05)$ Nitrogen levels: 3.00

Varieties: 2.00

Interaction: NS

Higher nitrogen use efficiency in $40 \mathrm{~kg} \mathrm{~N} / \mathrm{ha}$ might be due to lower nitrogen dose used in this treatment. Among the wheat varieties, PBW 175 recorded the highest nitrogen use efficiency. Kaur and Ram (2017) also recorded higher nitrogen use efficiency in lower dose of the nitrogen. Wheat varieties $\mathrm{C}$ 306 and WH 1080 were statistically similar in nitrogen use efficiency. The higher nitrogen use efficiency recorded in variety PBW 175 was due to higher grain yield. Kaur and Ram (2017) also reported variability in nitrogen use efficiency in different varieties. It can be concluded that, the nitrogen dose of $60 \mathrm{~kg}$ $\mathrm{N} / \mathrm{ha}$ can used under rainfed conditions in NW Indian conditions using variety PBW 175.

\section{References}

Bavar, M., Abad HHS and Noormohamadi G 2016. The effects of different levels of nitrogen on yield and yield components of rainfed wheat in two regions of North Khorasan. Open Journal of Ecology 6: 443-451.

Benin, G., Bornhofen E, Beche E, Pagliosa ES, da Silva CL and Pinnow C. 2012. Agronomic performance of wheat cultivars in response to nitrogen fertilization levels. Acta Scientiarum. Agronomy 34: 275-283.

Kaur, H., and Ram H 2017. Nitrogen management of wheat cultivars for higher productivity - A review. Journal 
of Applied and Natural Science 9: 133143.

Krishnakumari, M., R. K. Sharma, and S. S.

Balloli. 2000. Effect of late application of nitrogen on yield and protein content of Wheat. Annals Agricultural Research 21: 288-291.

\section{How to cite this article:}

Hari Ram, G.S. Mavi, Neha Gupta, S.S. Dhaliwal and Sohu, V.S. 2017. Productivity and Nitrogen Use Efficiency of Wheat Varieties in Relation to Nitrogen Levels under Rainfed Conditions of North-western India. Int.J.Curr.Microbiol.App.Sci. 6(10): 558-563. doi: https://doi.org/10.20546/ijcmas.2017.610.068 